cessfully bear the heavy burden, however, will not be penalized by an arbitrary disallowance. He can attempt to show the merits of his particular claim and will be judged thereon. If he chooses to contest a decision by the Commissioner, he does so with full knowledge of the difficulty.

The practice of medicine is continually changing with the increased accumulation of knowledge. A provision for tax relief must be sufficiently flexible to keep pace with these changes. The current definition of medical care, when applied by using the general tests, allows for such changes. As long as the purpose of the tax relief is to aid those afflicted with unusual medical burdens, the attainment of that goal should not be inhibited by a provision which may withhold the relief from the most burdened taxpayers.

\title{
FORUM-SHOPPING IN THE REVIEW OF NLRB ORDERS
}

A party who the National Labor Relations Board finds has committed an unfair labor practice may seek review of the Board's order in a United States Court of Appeals, 1 or the Board itself may petition a court of appeals to obtain judicial sanction for its order. ${ }^{2}$ The purpose of this comment is to explore the possibility of forum-shopping, ${ }^{3}$ especially with respect to an appeal by an aggrieved party, 4 and to determine the extent to which forum-shopping is practiced.

\section{I}

The accompanying chart comprises all cases decided by the courts of appeals from January, 1955, through November, 1960,5 in which the NLRB brought enforcement proceedings or an aggrieved party appealed a final Board order. The cases are tabulated with reference to the aggrieved party: an employer, a union or both. 6 A court's action with reference to each category

161 Stat. 148-49 (1947) (amended by 72 Stat. 945 (1958)), 29 U.S.C. $\S 160(f)$ (1958), hereinafter referred to as section 10(f), the section designation of the Labor Management Relations Act (Taft-Hartley Act), 61 Stat. 136 (1947).

261 Stat. 147-48 (1947) (amended by 72 Stat. 945 (1958)), 29 U.S.C. § 160(e) (1958), hereinafter referred to as section 10(e), the section designation of the Labor Management Relations Act (Taft-Hartley Act), 61 Stat. 136 (1947).

3 For the purposes of this comment, the term "forum-shopping" is applied whenever an appeal is taken to a court of appeals in a circuit other than where the unfair labor practice occurred, or where the aggrieved party has his principal place of business. In these situations, it will be assumed that the primary reason for the choice of forum is convenience.

4 An aggrieved party can be one against whom an order of the Board is issued, one who has had a complaint dismissed by the Board, or one who is partially in either category. See e.g., Kovach v. NLRB, 229 F.2d 138 (7th Cir. 1956); American Newspaper Publisher's Ass'n v. NLRB, 190 F.2d 45 (7th Cir. 1951); Albrecht v. NLRB, 181 F.2d 652 (7th Cir. 1950). Compare Amalgamated Meat Cutters \& Butcher Workmen v. NLRB, 267 F.2d 169 (1st Cir. 1959).

5 West Federal Reporter, Second Series, 218 F.2d to 284 F.2d.

6 Included in the category "orders against both" are those cases in which the Board's final order remedied only a portion of the alleged unfair labor practices for which the com- 


\begin{tabular}{|c|c|c|c|c|c|c|c|}
\hline \multirow{4}{*}{ 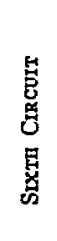 } & pegtpow & 100 & \multirow{2}{*}{$\vec{a}$} & \multirow{8}{*}{$\begin{array}{l}\text { 苑 } \\
\ddot{8} \\
\dot{0} \\
\dot{0}\end{array}$} & & & \multirow{6}{*}{ 오 } \\
\hline & pəฺ्̣व & $1=\overbrace{}^{\infty}$ & & & & & \\
\hline & pəэго子山् & r & గొ & & & & \\
\hline & [E०I & - gुक & in & & & & \\
\hline \multirow{4}{*}{ 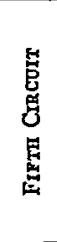 } & Pag!pow & Hম્స̈ & \multirow{2}{*}{ 感 } & & pəy!Po/K & Har & \\
\hline & pəẹua $\alpha$ & नస્స & & & pə!̣व $\propto$ & meN & \\
\hline & рәэлоти & 요 & ณ & & possojug & $\exists+\infty$ & : \\
\hline & [E]०L & $\vec{\sim} \infty N$ & 웜 & & IE7OLL & $\bar{m}^{\infty} m$ & ชี่ \\
\hline \multirow{4}{*}{ 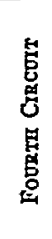 } & pey!poys & $1+0$ & \multirow{2}{*}{$\stackrel{\sim}{\exists}$} & \multirow{4}{*}{ 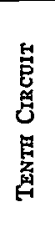 } & pэy!posर & -100 & \multirow{2}{*}{$H$} \\
\hline & 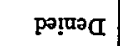 & |음- & & & pə!̣ue $\alpha$ & HNO & \\
\hline & pəosojugr & $N \infty$ & 요 & & parrogug & sort & 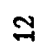 \\
\hline & [E7OC] & Ng్ & న్ & & [꾸이 & $-\infty-1$ & $\stackrel{2}{2}$ \\
\hline \multirow{4}{*}{ 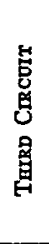 } & peg!post & Nus & \multirow{2}{*}{$\ddot{7}$} & \multirow{4}{*}{ 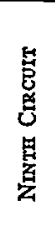 } & pəg!PoN & $+\infty 0$ & \multirow{2}{*}{ กิ } \\
\hline & pə!̣ua $\alpha$ & $m=0$ & & & pə̣̆ष्व & $r a \#$ & \\
\hline & pәэгојш & 윰표 & $\hat{N}$ & & рәэгојші & $\infty m^{n}$ & 吕 \\
\hline & [ETO] & 무요 & $\mathscr{F}$ & & [e7od & min & $\infty_{n}^{\infty}$ \\
\hline \multirow{4}{*}{ 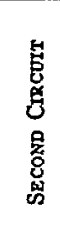 } & pәу!рог & Nesm & \multirow{2}{*}{$\vec{\sim}$} & \multirow{4}{*}{ 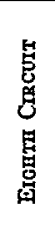 } & pagtposर & नात & \multirow{2}{*}{$\exists$} \\
\hline & pəฺ̣๐ & $\infty \nLeftarrow-1$ & & & pə!ष्व & 7130 & \\
\hline & pasrojug & mत्र & $\hat{m}$ & & pasxoуш & mี゙N & $F$ \\
\hline & [E7OL & జָన & $\infty$ & & [E70工 & चलूल & นึ \\
\hline \multirow{4}{*}{ 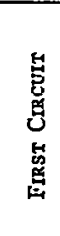 } & рәу!ро & timo & \multirow{2}{*}{$a$} & \multirow{4}{*}{ 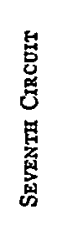 } & pэg!PoJt & ont & \multirow{2}{*}{ 요 } \\
\hline & pạıəa & 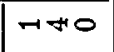 & & & pə!тra & +R्Nल & \\
\hline & pəsrojug & $\infty$ & సิ & & рәэготит & 음워 & 옥 \\
\hline & โ⿻上丨 & 으웜 & $\vec{m}$ & & [E]OL & सnल & 옹 \\
\hline & 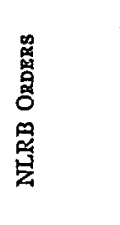 & 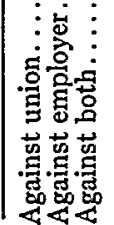 & 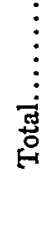 & & 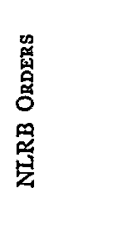 & 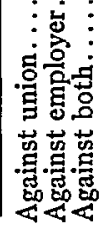 & 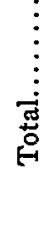 \\
\hline
\end{tabular}


of aggrieved parties is recorded as either enforcing the order, denying enforcement or enforcing the order as modified by the court.7

Over an extended period of time and a large number of cases, the probability is that each circuit will have considered substantially similar substantive issues of labor law. It is felt, therefore, that the tabulation of a large number of cases, coupled with a comparison of the cumulative results reached, will furnish a statistical guide to the "attitude" of one circuit relative to another. Relative attitudes of the courts should indicate whether forum-shopping would be profitable.

The chart evidences the attitude of a court in two ways. One is in the relative weight given to the Board's order without regard to which party is benefitted by the order. 8 A comparison of attitudes indicates that the Courts of Appeals for the Fifth and Seventh Circuits and the District of Columbia, where Board orders are enforced in full in approximately one-half of the cases, furnish the most favorable forums for an aggrieved party. On the other hand, the Courts of Appeals for the First, Third, Eighth and Tenth Circuits, where Board orders are enforced in full more than two-thirds of the time, afford the Board its best chance of obtaining enforcement.

Secondly, the chart indicates which forum is relatively advantageous for an appeal by either an employer or union. Thus, the Courts of Appeals for the Fifth and Seventh Circuits are much more favorable to an employer than are the Second and Third Circuits. On the other hand, the Courts of Appeals for the Second Circuit and the District of Columbia are the most favorable forums for a union review petition. 9

Research has indicated that the judicial attitudes inferable from the chart

plaint was filed and dismissed the remainder. In the case of such a "partial" order, both the complainant and the party against whom the order was issued are aggrieved. Both thus have standing to appeal the Board's action, as is the case when the order is against both union and employer. See, e.g., Superior Derrick Corp. v. NLRB, 273 F.2d 891 (5th Cir. 1960); Local 67, Teamsters Union v. NLRB, 257 F.2d 194 (D.C. Cir. 1958). But cf. NLRB v. Englander Co., 237 F.2d 599 (3d Cir. 1956).

7 Section $10(e)$. The court has jurisdiction "to make and enter a decree enforcing, modifying, and enforcing as so modified, or setting aside in whole or in part the order of the Board." Similar provision is made in section 10(f). If an order was set aside only in part, it is recorded as modified by the court.

8 A similar method of comparing treatment accorded Board orders in the various circuits was used by Cooper, Administrative Law: The "Substantial Evidence" Rule, 44 A.B.A.J. 945 (1958).

The cases in each circuit in which enforcement was denied and those in which an order was enforced as modified are combined in one total, which can then be compared with the total in which an order was enforced in full. Since a modification differs only in degree from a denial of enforcement, the benefit to an aggrieved party of either result, as opposed to enforcement in full, is clear.

9 Although no combined total is shown, here also the total number of cases enforced in full should be compared with the total number of cases in which an order was denied enforcement or enforced only as modified. 
do not vary as a function of the procedual setting in which the cases are presented. Whether the aggrieved party or the Board is the petitioner, the cumulative results in each circuit are similar. The chart was simplified by not classifying the cases according to procedural setting.

Several limitations of the tabulation should be noted. The substantive issues of labor law involved in the cases have not been examined. Therefore, no valid conclusions can be drawn regarding possible differences among the circuits in their application of substantive law. Nor will the factual situation of a particular case necessarily evoke a court's generally favorable attitude, which is evidenced only cumulatively over a large number of cases. Also, no criticism of a particular court of appeals can be made on the basis of the chart. The substantive issues in individual cases will determine whether court $A$ is "wrong" for denying enforcement more often than court B; or, whether B is "wrong" for not denying enforcement as often as A.10 Similarly, an inquiry into the underlying reasons for the clearly divergent results among the circuits is outside the scope of this comment.11 For present purposes, the fact that the results have been different is sufficient.

\section{II}

Before an aggrieved party can enjoy the advantage of a more favorable forum, the venue provisions of section $10(f)^{12}$ must be met:

Any person aggrieved by a final order of the Board granting or denying in whole or in part the relief sought may obtain a review of such order in any United States Court of Appeals in a circuit wherein the unfair labor practice in question was alleged to have been engaged in or wherein such person resides or transacts business, or in the United States Court of Appeals for the District of Columbia. . . .13

10 If the assumption that cumulative statistics will annul any difference in substantive issues decided by the various circuits is incorrect, perhaps both A and B are "right."

11 Cooper, supra note 8, suggests that the courts of appeals differ in their application of the substantial evidence test enunciated in Universal Camera Corp. v. NLRB, 340 U.S. 474 (1951), and NLRB v. Pittsburgh S.S. Co., 340 U.S. 498 (1951). Cf. Jaffe, Judicial Review: Substantial Evidence on the Whole Record, 64 HARV. L. REv. 1233, 1239 (1951); the opinion of L. Hand, J., in NLRB v. Universal Camera Corp., 190 F.2d 429, 430 (2d Cir. 1951) (on remand from the Supreme Court): The intent of Congress was "to prescribe an attitude in courts of appeal less complaisant towards the Board's findings than had been proper before; not only were they to look to the record as a whole, but they were to be less ready to yield their personal judgment on the facts; at least less ready than many at times had been." The cases which make up the present chart, however, were not all cases in which the substantial evidence rule was controlling, since many turned on purely legal questions.

12 See Comment, 8 STAN. L. REv. 472 (1956), for an extensive analysis of this venue provision, together with citations to relevant congressional history. For present purposes, only a brief summary is necessary to indicate the possibilities for forum-shopping which are available.

1361 Stat. $148-49$ (1947), as amended, 72 Stat. 945 (1958), 29 U.S.C. § 160(f) (1958). Substantially similar venue provisions govern appeals from other administrative agencies. See, e.g., 72 Stat. 795 (1958), 49 U.S.C. $\$ 1486(b)$ (1958) (CAB); 52 Stat. 831 (1938), as amended, 72 Stat. 946 (1958), 15 U.S.C. $\$ 717$ (b) (1958) (FPC); 52 Stat. 1028 (1938), as 
In an enforcement proceeding under section 10(e), the Board has the same choice of venue, except that the Court of Appeals for the District of Columbia is not available as an independent forum. ${ }^{14}$

On its face, section 10(f) provides only three alternative forums: the situs of the unfair labor practice, the District of Columbia or the circuit wherein the aggrieved party "transacts business." 15 The number of available forums, however, is greatly increased by the latitude of the phrase "transacts business." If an enterprise maintains a relatively minor storage depot in a circuit geographically removed from its principal office, it transacts business there for the purpose of laying venue. ${ }^{16}$ Indeed, the enterprise need have no physical facility in the circuit; it is sufficient if orders are solicited and goods are shipped to dealers there. ${ }^{17}$ In view of these broad venue provisions, the possibility of more than one court reviewing the same NLRB order is ever-present. A Board order against both employer and union ${ }^{18}$ raises the problem in its most acute form. Both parties then have a right to appeal the order. This situation affords the possibility of at least three proceedings in three different circuits: by the employer and union on appeal, and by the Board for enforcement.

Prior to 1958 there was no statutory provision to cover the situation where more than one proceeding was instituted seeking review of the same Board order. The judiciary, however, had worked out a procedure to meet the problem. The court in which the NLRB filed the transcript of the Board hearings obtained exclusive jurisdiction of the entire controversy, ${ }_{19}^{19}$ even though one or more aggrieved parties had previously appealed in another

amended, 72 Stat. 942 (1958), 15 U.S.C. \$45(c) (1958) (FTC); 41 Stat. 492 (1920), as amended, 54 Stat. 912 (1940), 49 U.S.C. $\$ 16(2)$ (1958) (ICC). There is a significant difference, however, in the provisions for the $\mathrm{CAB}$ and FPC: the requirement is for appeal in the circuit of the person's "principal place" of business, rather than merely where he "transacts business."

1461 Stat. 147-48 (1947), as amended, 72 Stat. 945 (1958), 29 U.S.C. §160(e) (1958).

15 Conceivably, if an unfair labor practice occurred in the District of Columbia, and that were the only place in which the employer (assuming that he is the aggrieved party) transacted business, then there would be no choice involved. This must, however, be the rare situation.

16 Olin Indus., Inc. v. NLRB, 191 F.2d 613 (5th Cir. 1951). Cf. NLRB v. Texas Independent Oil Co., 232 F.2d 447 (9th Cir. 1956).

17 Eastman Kodak Co. v. Southern Photo Materials Co., 273 U.S. 359 (1927), relied on in NLRB v. Friedman-Harry Marks Clothing Co., 83 F.2d 731 (2d Cir. 1936). Cf. International Shoe Co. v. Washington, 326 U.S. 310 (1945). Nor is the usefulness of the phrase limited to employers. National Marine Eng'rs Beneficial Ass'n v. NLRB, 274 F.2d 167 (2d Cir. 1960).

18 Fifty-seven such orders have been the subject of court of appeals action since 1955 . See, e.g., Piasecki Aircraft Corp. v. NLRB, 280 F.2d 575 (3d Cir. 1960) (partial order); NLRB v. Turner Constr. Co., 227 F.2d 498 (6th Cir. 1955).

19 ILGWU v. NLRB, 225 F.2d 923 (D.C. Cir. 1955). 
circuit. The court in which the appeal had been originally filed transferred the case to the court chosen by the Board, and both proceedings were consolidated in one action. 20

In 1958, to promote simplicity and uniformity in the procedure of appeals from all administrative agency decisions, 21 sections $10(\mathrm{e})$ and $10(\mathrm{f})$, plus the provisions for appeal from twenty-one other administrative agencies, were amended,22 and section 2112 was added to Title 28.23 The new legislation removed the power to choose the forum from the NLRB. If proceedings are instituted in more than one circuit with respect to the same order, the Board must file the record in the court in which a proceeding was first instituted. "The other courts in which such proceedings are pending shall thereupon transfer them to the court of appeals in which the record has been filed."24

Section 2112 further provides that "for the convenience of the parties and in the interest of justice such court [which has obtained exclusive jurisdiction of the proceedings] may thereafter transfer all the proceedings with respect to such order to any other court of appeals." 25 The extent to which this remedial forum non conveniens provision ${ }^{26}$ will obviate the possibility of forum shop-

20 See NLRB v. Standard Oil Co., 124 F.2d 895 (10th Cir. 1941); Stanolind Oil \& Gas Co. v. NLRB, 116 F.2d 274 (5th Cir. 1940); Standard Oil Co. v. NLRB, 114 F.2d 743 (8th Cir. 1940) (All three cases were concerned with the same unfair labor practices, which occurred in the Tenth Circuit, where the Board filed the record); NLRB v. Friedman-Harry Marks Clothing Co., 85 F.2d 1 (2d Cir. 1936); Friedman-Harry Marks Clothing Co. v. NLRB, 84 F.2d 1000 (4th Cir. 1936) (memorandum decision); NLRB v. Friedman-Harry Marks Clothing Co., 83 F.2d 731 (2d Cir. 1936). (All three cases were concerned with the same unfair labor practices, which occurred in the Fourth Circuit; the Board, however, filed the record in the Second Circuit).

21 "The purpose of the proposed legislation is to save time and expense by permitting the several courts of appeals to adopt rules authorizing the abbreviation of the transcript and other parts of the record made before Federal administrative agencies when the orders of those agencies are to be reviewed by the courts of appeals." S. REP. No. 2129, 85th Cong., 2d Sess. 1 (1958).

2272 Stat. 941 (1958).

2328 U.S.C. $\S 2112$ (1958).

2428 U.S.C. $\$ 2112$ (a) (1958).

$25 \mathrm{Ibid}$. As originally introduced, the 1958 bill would have given statutory blessing to the method already in use by which the Board determined the forum by filing the record, subject to a limitation that the convenience of the parties and the interests of justice be considered. Hearings Before the House Committee on the Judiciary, 84th Cong., 2d Sess., ser. 25, at 1 (1956). To avoid anticipated abuse of agency discretion, the bill was amended and passed in its present form. Id. at 13; H. REP. No. 842, 85th Cong., 1st Sess. 4-5 (1957).

Congressional anticipation of agency abuse, however, is not supported by NLRB action from 1955 to 1958 . In only one instance since 1955 has the Board petitioned outside the circuit wherein the unfair labor practice occurred. Further, from 1955 until the new provisions became effective in 1958, there was no instance of the Board choosing to file a transcript of the record in a circuit other than the one in which a review petition had already been filed.

${ }^{26}$ It is possible that forum non conveniens was available to the courts in NLRB cases prior to 1958, under 28 U.S.C. $\$ 1404$ (a) (1958). Cf. United States v. National City Lines, 
ping is still open to speculation. Thus far, only one reported case has been transferred from the circuit in which a review petition was first filed.27

\section{III}

Despite the opportunities which are available, and the apparent difference in attitude among the circuits, there is surprisingly little forum shopping in actual practice. Of the 563 cases tabulated for this comment, 411 were section $10(\mathrm{e})$ enforcement proceedings by the Board. Only one of these was taken to a court of appeals outside of the circuit in which the unfair labor practice occurred.28

Of the remaining 152 cases, 89 were appeals by aggrieved employers. Only 13 were appealed in a circuit other than where the unfair labor practice occurred. The basis for five of these appeals can reasonably be interpreted as convenience, since they were taken in the circuit in which the employer had its principal place of business.29 Eight of the employer appeals, however,

Inc., 337 U.S. 78 (1949); Ex parte Collett, 337 U.S. 55 (1949). But the applicability of section 1404(a) to NLRB proceedings was never expressly decided. Prior to its enactment, the doctrine was rejected in NLRB v. Indiana \& Michigan Elec. Co., 124 F.2d 50, 53 (6th Cir. 1941). See generally, Kaufman, Observations On Transfers Under Section 1404(a) of the New Judicial Code, 10 F.R.D. 595, 605-07 (1950); 1 BARRON \& HoltzofF, FedERAL PRACTICE \& Procedure $\$ 87$ (1960). Cf. Hoffman v. Blaski, 363 U.S. 335 (1960); Norwood v. Kirkpatrick, 349 U.S. 29 (1955); Gulf Oil Corp. v. Gilbert, 330 U.S. 501 (1947).

27 Local 2674, United Bhd. of Carpenters \& Joiners v. NLRB, 4 CCH LAB. REL. REP. (41 L.C.) I 16580 (Sept. 16, 1960). The employer, Butcher Boy Refrigerator Door Company, against whom the Board's order was entered, intervened in the Court of Appeals for the District of Columbia, where the complainant-union had petitioned for review, and requested the court to transfer the case to the Seventh Circuit. Pointing out that neither employer nor union carried on activities in the District of Columbia and that all of the events in the case occurred in the Seventh Circuit, the company asserted that the union had only two reasons for petitioning in the District: to harass the employer by causing additional expense and to obtain a favorable forum. Brief for the Intervenor, pp. 5-7. The employer noted in passing that there was doubt that the union was even an aggrieved party, since the Board's order granted relief from all of the important unfair practices alleged in the union's complaint to the NLRB. Id. at 8.

The Court of Appeals for the District of Columbia did not cite section 2112 as authority for granting the employer's motion to transfer the case to the Seventh Circuit. Since, however, the forum non conveniens provision of section 2112(a) furnished the thrust of the employer's arguments, it is probable that the court acted under that section.

28 NLRB v. Perry, 244 F.2d 17 (4th Cir. 1957). Perry operated a small sawmill in Chama, New Mexico, where the unfair labor practices occurred. There is nothing in the report of the case or in the trial examiner's report (IR-(SF)-385 (1955)) to indicate the basis of the jurisdiction of the Fourth Circuit.

Of the 411 cases, 30 in the Eighth Circuit and 3 in the Sixth were enforced by memorandum opinions, with nothing to indicate the situs of the unfair labor practices. For the purpose of this comment, it is assumed that all were enforced in the circuit in which the practices occurred.

29 Food Fair Stores of Florida, Inc. v. NLRB, 275 F.2d 845 (3d Cir. 1960) (unfair labor practices in Florida); National Van Lines, Inc. v. NLRB, 273 F.2d 402 (7th Cir. 1960) (unfair labor practices in California); United Ins. Co. of America v. NLRB, 272 F.2d 446 (7th Cir. 1959) (unfair labor practices in Pennsylvania); Allis-Chalmers Mfg. Co. v. NLRB 
appear to have been based on expected secondary advantages from the forum selected: two cases were taken to the Seventh Circuit and one to the Fifth. 30 These circuits appear to be the most favorable to employers. The other five cases were appealed in the District of Columbia, where Board orders are treated (statistically) with less deference than in the circuits where the alleged unfair practices occurred. 31

The remaining 63 cases involved union appeals. Forty-one of these were appealed in a circuit other than the one where the unfair labor practice occurred: one in the Second Circuit, which appears to have been for reasons other than convenience, 32 and forty in the District of Columbia. 33 The Second and District of Columbia Circuits appear to be relatively the most favorable for a union appeal. In fourteen of the cases before the Court of Appeals for the District of Columbia appellants maintained their principal offices in the

261 F.2d 613 (7th Cir. 1958) (unfair labor practices in Pennsylvania); A. M. Andrews Co. v. NLRB, 236 F.2d 44 (9th Cir. 1956) (unfair labor practices in Illinois).

The attorney for Allis-Chalmers has stated that his reason for appealing to the Seventh Circuit was convenience. Letter from John $\mathrm{H}$. Kamps to The University of Chicago Law Review, Feb. 4, 1961, on file in The University of Chicago Law Library.

30 Celanese Corp. of America v. NLRB, 279 F.2d 204 (7th Cir. 1960) (unfair labor practices and principal place of business in West Virginia); Sunshine Biscuits, Inc. v. NLRB, 274 F.2d 738 (7th Cir. 1960) (unfair labor practices in Pennsylvania, principal place of business in New York); General Motors Corp. v. NLRB, 222 F.2d 349 (5th Cir. 1955) (unfair labor practices in New York, principal places of business in New York and Michigan).

The attorney for Sunshine Biscuits has stated that his reason for appealing to the Seventh Circuit was his belief that the "case was indistinguishable from [Miller Elec. Mfg. Co.v. NLRB, 265 F.2d 225 (7th Cir. 1959)]." He thought that the "chances for a more favorable ruling were much greater before a court that had passed on the problem." Letter from David B. Buerger to The University of Chicago Law Review, Feb. 7, 1961, on file in The University of Chicago Law Library.

31 Puerto Rico S.S. Ass'n v. NLRB, 281 F.2d 615 (D.C. Cir. 1960) (unfair labor practices and principal place of business in Puerto Rico); Honolulu Star-Bulletin, Ltd. v. NLRB, 274 F.2d 567 (D.C. Cir. 1959) (unfair labor practices and principal place of business in Hawaii); News Printing Co. v. NLRB, 231 F.2d 767 (D.C. Cir. 1956) (unfair labor practices and principal place of business in New Jersey); Richfield Oil Corp. v. NLRB, 231 F.2d 717 (D.C. Cir. 1956) (unfair labor practices and principal place of business in California); Union Mfg Co. v. NLRB, 221 F.2d 532 (D.C. Cir. 1955) (unfair labor practices and principal place of business in Maryland).

32 National Maritime Eng'rs Beneficial Ass'n v. NLRB, 274 F.2d 167 (2d Cir. 1960). The court had jurisdiction because petitioners (two unions) had offices and did business in the Second Circuit. Id. at 169. The unfair labor practices occurred in the Seventh Circuit. The union offices maintained in the Second Circuit do not appear to be the main offices, although their exact location has not been determined.

33 The unfair labor practices in these cases occurred as follows: 1st Circuit, 0; Second Circuit, 3; Third Circuit, 1; Fourth Circuit, 3; Fifth Circuit, 9; Sixth Circuit, 6; Seventh Circuit, 6; Eighth Circuit, 2; Ninth Circuit, 6; Tenth Circuit, 3. In Insurance Agents' Int'l Union v. NLRB, 260 F.2d 736 (D.C. Cir. 1958), the unfair labor practice had no particular situs. The union is the bargaining agent for all of Prudential Insurance Company's district agents. 
District;34 the purpose of these appeals can reasonably be termed convenience. In the remaining twenty-six, however, the union's principal office was in another circuit. The selection of the District of Columbia, therefore, appears to have been motivated by expected advantages from the forum.

Thus, 35 of the 152 petitions for review of Board orders appear to have involved shopping for a more favorable forum. Since all of the 563 Board orders which comprise the accompanying chart could have been appealed by the aggrieved parties, the number which actually involved forum-shopping is relatively small. There are several possible explanations for this phenomenon. It has been suggested that the financial burden involved in an appeal is an important factor which negates any advantage to be gained from forumshopping. 35 This contention, however, is valid only as an argument against appeals in general, not against forum-shopping in particular. It might explain why only 152 appeals were taken from 563 appealable orders. It does not explain the existence of only 35 cases of forum-shopping. 36

The apparent absence of forum-shopping may be better explained, although still only partially, by another factor. When an employer is aggrieved by a Board order with respect to an unfair labor practice which arises in either the Fifth or Seventh Circuits, there is no reason for him to seek another forum. Since the Board uniformly (only one exception) brings enforcement proceedings in the circuit in which the practice occurred, the employer will automatically be in one of the two circuits which are most favorable to him. Thus, in the 123 orders against employers arising from unfair labor practices in these two circuits, 37 one would not expect to find a change of forum. An aggrieved employer in either the Fifth or Seventh Circuits would have to appeal a Board order only if a union were also aggrieved, in order to forestall a possible union appeal to another circuit.

An explanation for the absence of forum-shopping in the Fifth Circuit may lie in the antipathy evinced by the court of appeals in the only case of forumshopping in that circuit since 1955:

34 The location of the principal offices of the union-appellants is taken from INTERNATIONAL LABOR DIRECTORY \& HANDBOOK (1955).

35 Humphrey, The National Labor Relations Board and the Courts, N.Y.U. 8TH ANNUAL CONFERENCE ON LABOR 121, 132-35 (1955). Humphrey's main argument is directed to the advantage of waiting for the Board to bring enforcement proceedings, thus avoiding certain costs of appeal, such as the requirements that the petitioner furnish the transcript of record.

36 Indeed, Humphrey, supra note 35, at 135 n.7, seems to recognize this in a concluding statement that is somewhat inconsistent with her thesis: "Of course where the respondent [aggrieved party] has substantial operations in various circuits, especially where the conduct complained of occurred in more than one locale, it may be worthwhile to get into a more advantageous court before the Board selects another." The basis for the assumption that there may exist "a more advantageous court" is not enunciated.

37 This is the total number of cases in the Fifth and Seventh Circuits in which an employer was an aggrieved party, minus the number of appeals with respect to unfair labor practices which occurred outside of the circuits. 
Basing jurisdiction on the alleged fact that petitioner does business in both Florida and Georgia within the Fifth Circuit, this action was brought here in spite of the fact that the petitioner is a Delaware corporation with its plant and the situs of operations out of which the proceeding arises, were all located and took place in the Second Circuit. ${ }^{38}$

The critical attitude displayed may offset any advantage which might be gained from the court's general employer-oriented attitude. The Courts of Appeals for the Second and Seventh Circuits and the District of Columbia, the only other circuits in which forum-shopping was found, have not shown a similar antipathy, ${ }^{39}$ although if any of these courts were faced with a case of obvious forum-shopping, such antipathy might appear.

There is another possible explanation for the failure to practice forumshopping on a wider scale. Certain courts of appeals evince attitudes more favorable to the Board, an employer or a union. The overall attitude of a court, however, may not control a particular case. For example: the Board determines that an employer committed an unfair labor practice in the Eighth Circuit; the employer also transacts business in the Seventh Circuit; the Seventh appears more favorable to him as an employer, but the Eighth has recently decided in his favor a case "on all fours" with the order against him. The employer's attorney will not be inclined to forum-shop. 40 In cases where a choice of forum is available, the existence of a controlling precedent will dictate the choice; but when there is no decision in any circuit directly in point, the general attitude of a court may still be decisive. 41

\section{IV}

As noted above, the number of cases in which forum-shopping was actually practiced is relatively small when compared with the total number of cases considered by the courts of appeals. If some of the explanations for this phenomenon are valid, the significance of the number of forum-shopping cases is increased. In any event, thirty-five examples of the practice seem sufficient to justify consideration of possible changes in the liberal venue pro-

38 General Motors Corp. v. NLRB, 222 F.2d 349, 350 (5th Cir. 1955) (Board's order affirmed). In accord with this attitude is Olin Indus., Inc. v. NLRB, 191 F.2d 613, 614 n.1 (5th Cir. 1951): "Its [petitioner's] plant is situated at New Haven, Connecticut [the situs of the unfair labor practice]. ... The Board concedes that this Court has jurisdiction over the instant proceeding because petitioner happens to have a warehouse in Houston, Texas."

39 In view of the express statutory permission to appeal to the District of Columbia, such an attitude would not be expected by that court of appeals.

40 A case "on all fours," however, may also be the controlling factor which leads to forum-shopping. See letter from David $B$. Buerger, supra note 30.

41 A final explanation for the dearth of forum-shopping lies in the possibility that attorneys simply are not aware that certain forums are more favorable than others. A limited sampling of practicing attorneys' opinions, given off-the-record, indicates that this is generally not the case. 
visions of sections $10(\mathrm{e})$ and $10(\mathrm{f})$, which supposedly are available for the convenience of the litigants. 42

Apart from the number of cases, the problems inherent in those cases in which more than one party is aggrieved ${ }^{43}$ are indicative of the need to limit the presently available choices of forums. Two cases which have not yet received final court of appeals action (and thus are not included in the tabulation of cases) are illustrative. In the Butcher Boy case, 44 the employer appealed to the Seventh Circuit. The union, however, had previously petitioned in the District of Columbia to give that circuit exclusive jurisdiction of the case. 45 Butcher Boy Refrigerator Door Company is a small business in Illinois, in the Seventh Circuit, where the alleged unfair labor practices occurred. The complaining union, the Brotherhood of Carpenters and Joiners, has its principal office in Indiana, also in the Seventh Circuit. Clearly the Seventh Circuit would afford the most convenient forum for all of the parties. Indeed, the Court of Appeals for the District of Columbia transferred the case, at the instigation of the employer, to the Seventh Circuit. 46

The second case involves a Board order against the Kohler Company.47 The Board dismissed a major portion of the complaint of the United Auto Workers, so that both employer and union were aggrieved parties. The company's plant is located in Wisconsin, in the Seventh Circuit, where all of the alleged unfair labor practices occurred. The principal office of the UAW is in Michigan, in the Sixth Circuit. On the facts of the case, only the Sixth and Seventh Circuits can reasonably be viewed as convenient for all parties. Within thirty minutes after the Board issued its order, however, the UAW filed a petition for review in the District of Columbia. The company consumed only ninety minutes in petitioning for review in the Seventh Circuit.48

42 Cf. Hearings Before Subcommittee No. 3 and Subcommittee No. 4 of the House Committee on the Judiciary, 80th Cong., 1st Sess., ser. 2, at 29 (1947) (statement of Judge Phillips concerning a bill to amend appellate procedure from the ICC and FCC); Hearings on $S$. 1567 and H.R. 1639 Before a Subcommittee of the Senate Committee on the Judiciary, 80th Cong., 2d Sess. 3 (1948) (a bill to amend the FELA venue provisions); Hearings Before the House Committee on the Judiciary, 84th Cong., 2d Sess., ser. 25, at 14 (1956) (statement of Representative Crumpacker concerning the proposed Section 2112 of Title 28).

${ }^{43} \mathrm{Cf}$. text accompanying note 18 supra; text following note 37 supra.

44 Butcher Boy Refrigerator Door Co. v. NLRB, 127 N.L.R.B. — (No. 160) (1960).

45 Pursuant to 28 U.S.C. \$2112(a) (1958). The Seventh Circuit transferred the employer's appeal to the District of Columbia. 4 CCH LAB. REL. REP. (41 L.C.) II 16557 (Sept. 21, 1960).

46 Local 2674, United Bhd. of Carpenters \& Joiners; 4 CCH LAB. REL. REP. (41 L.C.) I 16580 (Sept. 16, 1960). The Seventh Circuit subsequently accepted jurisdiction. Butcher Boy Refrigerator Door Co. v. NLRB, 4 CCH LAB. ReL. ReP. (41 L.C.) T 16581 (Oct. 7, 1960).

${ }^{47}$ Kohler Co. v. Local 833, UAW-AFL-CIO, 128 N.L.R.B. - (No. 122) (1960).

48 This information was supplied in a letter from Francis E. Hickey, member of the Illinois bar, to the University of Chicago Law Review, Feb. 3, 1961, on file in The University of Chicago Law Library.

For an account (somewhat less than favorable to the union and the NLRB) of the back- 
A more farcical illustration of the extremes to which overly permissive venue leads is hard to imagine. If this race for a favorable forum were the sole instance of forum-shopping, reappraisal of the venue provisions would be justified.

Although the present forum non conveniens provision of section 2112 may prove capable of curtailing such abuses, there is no apparent reason to place the entire burden of choosing proper venue on the courts of appeals. Minor changes in the present provisions would almost entirely remove the burden from the courts, and also virtually eliminate the abuses which wide choice of venue makes possible. It has been proposed that appeals from an order of the NLRB be available only in the court of appeals for the circuit where the unfair labor practice occurred. 49 To confine the choice of venue within such narrow limits, however, seems neither necessary nor desirable. Forum-shopping, as the term has been used in this comment, does not occur when an appeal is taken in the circuit where the unfair labor practice occurred or where the aggrieved party has its principal place of business. The definition seems justified by the rationale behind allowing any choice of venue: convenience of the parties. Pursuant to this definition of forum-shopping, the venue provisions should be redrafted to allow an appeal only in the circuit wherein the unfair labor practices occurred or in the circuit wherein the aggrieved party has its principal place of business. The forum non conveniens provision should be retained, although it should rarely be needed. The phrase "transacts business," with its potential for abuse, should be omitted, as should the alternative choice of the Court of Appeals for the District of Columbia.50 In a particular case, abuse of the provisions even as thus limited is conceivable. But any change must be weighed against the convenience of the parties. It is submitted that the availability of the forum where the practice occurs or where the aggrieved party maintains its principal place of business adequately provides for this convenience, and at the same time minimizes abuse. 51

ground of the Kohler strike and the subsequent Board order, See PeTRo, THE KoHLER STRIKE (1961).

49 Note, 8 STAN. L. Rev. 472 (1956). This note also favored a forum non conveniens provision to allow a court of appeals thereafter to transfer the case to another circuit.

${ }^{50}$ No justification for this alternative forum has been discovered. Since it is presently available only to aggrieved parties, convenience for the NLRB, which sits in Washington, D.C., is not a factor. Nor is any benefit to aggrieved parties apparent.

51 Another method by which forum-shopping could be limited is to eliminate the apparent divergency among the circuits in their treatment of NLRB findings of fact. $C f$. Cooper, supra note 8, where the "clearly erroneous" test is suggested as an alternative to the "substantial evidence" test presently in use. A slight change in the venue provisions appears to be a much easier remedy. Also, if there is in fact a difference in "attitude" among the circuits, more is necessary than a mere verbal alteration of the test to be applied to factual findings. $C f$. Jaffe, supra note 11 , at 1239 . 